\title{
Polymorphisms in thymidylate synthase and reduced folate carrier (SLC19A1) genes predict survival outcome in advanced non-small cell lung cancer patients treated with pemetrexed-based chemotherapy
}

\author{
WEN-JUAN LI ${ }^{1,2}$, HUA JIANG ${ }^{1}$, XIN-JIAN FANG ${ }^{1}$, HONG-LING YE ${ }^{1}$, MING-HUAN LIU ${ }^{1}$, YAN-WEN LIU ${ }^{1}$, \\ QIAN CHEN ${ }^{1}$, LI ZHANG ${ }^{1}$, JIN-YU ZHANG ${ }^{1}$, CHUN-LUAN YUAN $^{1}$ and QIU-YUN ZHANG ${ }^{1}$ \\ ${ }^{1}$ Department of Medical Oncology, The Second People's Hospital of Lianyungang \\ (Lianyungang Hospital Affiliated to Bengbu Medical College), Jiangsu 222000, P.R. China
}

Received September 9, 2012; Accepted January 2, 2013

DOI: 10.3892/ol.2013.1175

\begin{abstract}
The aim of this study was to evaluate the association between thymidylate synthase (TS), methylenetetrahydrofolate reductase $(M T H F R)$ and reduced folate carrier (SLC19A1) gene polymorphisms and the treatment efficacy of pemetrexed-based chemotherapy in advanced non-small cell lung cancer (NSCLC). Advanced NSCLC patients received pemetrexed and cisplatin every three weeks. Polymorphisms in the TS, MTHFR and SLC19A1 genes were detected in peripheral blood samples using DNA sequencing and Taqman PCR. An analysis of gene polymorphisms was performed with respect to the progression-free survival (PFS), response rate (RR) and overall survival (OS) of patients treated with pemetrexed. The median PFS times for patients with the TS $2 \mathrm{R} / 2 \mathrm{R}, 2 \mathrm{R} / 3 \mathrm{C}$ or $3 \mathrm{C} / 3 \mathrm{C}$ genotypes were significantly longer than those of patients with the $2 \mathrm{R} / 3 \mathrm{G}, 3 \mathrm{C} / 3 \mathrm{G}$ or $3 \mathrm{G} / 3 \mathrm{G}$ genotypes $(\mathrm{P}=0.036)$. Patients with the $S L C 19 A 1 \mathrm{CC}$ genotype had a significantly longer median OS compared with individuals with the homozygous and heterozygous genotypes (12.2 vs. 8.9 and 7.3 months, respectively; $\mathrm{P}=0.022$ ). The PFS and OS did not differ for the three genotypes of $M T H F R$ assessed. The $\mathrm{RR}$ was higher in patients with the $T S 2 \mathrm{R} / 2 \mathrm{R}, 2 \mathrm{R} / 3 \mathrm{C}$ or $3 \mathrm{C} / 3 \mathrm{C}$ genotypes than in the other groups $(\mathrm{P}=0.044)$. The polymorphisms of the 5'-UTR of the TS gene and exon 6 (2522) C/T of the SLC19A1 gene predict the survival of advanced NSCLC
\end{abstract}

Correspondence to: Professor Hua Jiang, Department of Medical Oncology, The Second People's Hospital of Lianyungang (Lianyungang Hospital Affiliated to Bengbu Medical College), 41 Hailian East Road, Lianyungang, Jiangsu 222000, P.R. China E-mail: jhufo@yahoo.com.cn

Present address: ${ }^{2}$ Department of Medical Oncology, Lujiang Country People's Hospital, Lujiang 231500, Anhui, P.R. China

Key words: pemetrexed, methylenetetrahydrofolate reductase, thymidylate synthase, SLC19A1, single nucleotide polymorphism, advanced non-small cell lung cancer patients treated with pemetrexed. However, a large scale clinical trial is required to validate these findings.

\section{Introduction}

Lung cancer is currently the most frequent cause of cancer mortality in the world and non-small-cell lung cancer (NSCLC) accounts for $\sim 80 \%$ of all lung cancer cases (1).Moreover, the 5 -year survival of NSCLC is only $15 \%$ (2), as most patients are diagnosed at an advanced stage of the disease when surgery options are limited. Thus, chemotherapy has become the most important treatment option for treating these patients. Platinum-based chemotherapy is considered to be the foundation of treatment for patients with advanced NSCLC, with a median overall survival (OS) of 8-11 months, and therefore may prolong survival and improve the quality-of-life for these patients (3). However, current chemotherapeutic approaches have had limited success and therefore novel agents are urgently required to improve outcomes. Pemetrexed is a United States Food and Drug Administration (FDA)-approved therapy for advanced NSCLC (4) and a large phase III study has demonstrated that pemetrexed in combination with cisplatin provides similar efficacy and improved tolerability compared with gemcitabine in combination with cisplatin for advanced NSCLC patients (5). The study also indicated that pemetrexed provides similar improvements for patients with adenocarcinoma. Pemetrexed is widely used for first- and second-line and maintenance therapy in NSCLC (4-6). However, in China Pemetrexed is considered to be an expensive drug and is therefore not widely used. Consequently, it is critical to identify patients who may benefit from pemetrexed therapy in order to reduce the side-effects and provide the most cost-effective approach. A number of clinical trials have attempted to identify molecular biomarkers which may be associated with the response and toxicity of pemetrexed $(7,8)$. The ultimate goal of this type of research is to create individualized treatment that provides an improved therapeutic profile by identifying the patients who are most likely to benefit from personalized therapy. 
Pemetrexed is a multi-targeted, folate-based anti-metabolite that has been shown to have anticancer activity in other tumor types, including cervical (9), pancreatic (10), colorectal (11), breast (12) and gastric (13) cancers. Pemetrexed inhibits several enzymes in the thymidine and purine biosynthetic pathways, including thymidylate synthase $(T S)$, dihydrofolate reductase $(D H F R)$, glycinamide ribonucleotide formyl transferase $(G A R F T)$ and aminoimidazole carboxamide ribonucleotide-formyl transferase $(A I C A R F T)$. Pemetrexed is transported into the cell by the reduced folate carrier $(R F C)$ system and is then rapidly and extensively polyglutamated by folylpolyglutamate synthase (FPGS). The drug is eliminated from the cell by $\gamma$-glutamyl hydrolase $(G G H)$.

$T S$ is a folate-dependent enzyme and the presence of a single nucleotide polymorphism (SNP) in the $T S$ promoter has been shown to be an independent factor in metastatic colorectal cancer patients treated with 5-fluorouracil (5-FU) (14). Methylenetetrahydrofolate reductase $(M T H F R)$ is a key enzyme in the folate metabolism pathway and MTHFR polymorphisms have been reported to correlate with the outcome of patients treated with methotrexate $(15)$ and pemetrexed $(16,17)$. The reduced folate carrier $S L C 19 A 1$ is responsible for the transport of pemetrexed and therefore genetic variations in the gene may affect the transport of the drug (18). The associations between the gene polymorphisms and drug efficacy remain controversial. At present, few studies have investigated the correlation between pemetrexed pathway-associated gene polymophisms and drug efficacy. Therefore, the present study examined the association between the gene polymorphisms and therapeutic results of pemetrexed treatment in NSCLC patients.

\section{Patients and methods}

Patient selection. Chemotherapy-naive patients who were $\geq 18$-years-old with histological or cytological evidence of measurable metastases or stage IIIB or IV NSCLC were enrolled in the present study. Other inclusion criteria included an Eastern Cooperative Oncology Group performance status (ECOG PS) $\leq 2$ and normal organ function, including adequate hepatic, renal and hematological function. Patients who had brain metastases were eligible if they had a life expectancy $\geq$ three months. Pregnant or lactating women were excluded from the study. All patients provided written informed consent prior to the initiation of treatment. Separate informed consent was obtained for the collection of blood samples for the study of single-nucleotide polymorphisms (SNPs). This study was approved by the ethics committee of the Second People's Hospital of Lianyungang (Jiangsu, China).

Treatment. Pemetrexed $\left(500 \mathrm{mg} / \mathrm{m}^{2}\right)$ was administered to patients as a 10 min intravenous (i.v.) infusion on day 1 of a 21 day cycle with cisplatin $\left(75 \mathrm{mg} / \mathrm{m}^{2}\right.$, i.v.) administered on days 1-3 every three weeks. All patients received daily oral supplements of folic acid (350-1000 $\mu \mathrm{g}$ ) 5-7 days prior to the first day of administration and the supplementation was continued for three weeks after the treatment ended. Vitamin $\mathrm{B}_{12}(1000 \mu \mathrm{g})$ was administered by intramuscular (i.m.) injection every three cycles of treatment. Dexamethasone $(4 \mathrm{mg}$ ) was administered orally twice a day on the day before, day of and day after each dose of pemetrexed therapy to prevent allergic reactions.
Treatment evaluation. All patients received complete clinical and laboratory evaluations prior to each cycle of treatment, including patient histories, physical examination, complete blood count, serum chemistry profile, electrocardiography (ECG) and radiological evaluation. Computed tomography (CT) and/or magnetic resonance imaging (MRI) were performed to evaluate the tumor response after every two cycles of therapy. The treatment effect was assessed according to the Response Evaluation Criteria in Solid Tumors (RECIST) (19) and categorized as complete response (CR), partial response $(\mathrm{PR})$, stable disease (SD) or progressive disease (PD).

DNA extraction. A $5 \mathrm{ml}$ aliquot of blood was collected from each patient into an EDTA-coated tube before they underwent the first drug cycle. Genomic DNA was extracted from peripheral blood cells using the Blood DNA kit (Omega Bio-Tek, Norcross, GA, USA) according to the manufacturer's instructions.

TS genotyping. DNA was amplified by polymerase chain reaction (PCR) using the following primers: 5'-AACTGTGCTGCT GGCTTAGA-3' (forward) and 5'-GTCTGTAAGGCGAG GAGGAC-3' (reverse). The TS gene promoter repeat and SNP (two or three repeats; $\mathrm{G}>\mathrm{C}$ within the second repeat of the $3 \mathrm{R}$ allele) polymorphisms were directly detected by DNA sequencing using an ABI Prism 3730 DNA analyzer (Applied Biosystems, Carlsbad, CA, USA). The $T S$ genotype was divided into low expression genotypes $(2 \mathrm{R} / 2 \mathrm{R}, 2 \mathrm{R} / 3 \mathrm{C}$ and $3 \mathrm{C} / 3 \mathrm{C})$ and high expression genotypes $(2 \mathrm{R} / 3 \mathrm{G}, \mathrm{C} / 3 \mathrm{G}$ and $3 \mathrm{G} / 3 \mathrm{G})$ according to the $\mathrm{SNP}$ and $T S$ genotype.

MTHFR and SLC19A1 SNP. MTHFR and SLC19A1 SNPs were detected using a Taqman minor groove binder (MGB) probe-based assay. The PCRs for the MTHFR and SLC19A1 genotypes were performed with a total volume of $5 \mu \mathrm{l}$, including 2.5 $\mu \mathrm{l}$ Taqman Master Mix, $0.25 \mu \mathrm{l}$ Taqman MGB primer probe, $1 \mu \mathrm{l}$ DNA and $1.25 \mu \mathrm{l}$ DEPC $\mathrm{H}_{2} \mathrm{O}$. The PCR cycling parameters were as follows: 45 cycles of $95^{\circ} \mathrm{C}$ for $10 \mathrm{~min}$, followed by $92^{\circ} \mathrm{C}$ for $15 \mathrm{sec}$ and $60^{\circ} \mathrm{C}$ for $90 \mathrm{sec}$. Genotyping was performed using the ABI 7900 HT Sequence Detector (Applied Biosystems) and analyzed by the Allelic Discrimination program (Applied Biosystems).

Statistical analysis. SPSS version 13.0 (SPSS, Inc., Chicago, IL, USA) was used for the data analyses. The primary end point was progression-free survival (PFS) and the secondary end points were objective response rate (RR) by RECIST and OS. PFS was measured from the time of randomization to disease progression or mortality from any cause, whichever occurred earlier. OS was measured from the time of randomization to the time of mortality from any cause. The Hardy-Weinberg equilibrium for gene polymorphisms was used to compare the observed distributions of genotype frequencies. Fisher's exact test was used to compare the treatment RRs between the genotypes. Kaplan-Meier curves and log-rank tests were also used to compare the OS and PFS distributions between the different SNP subgroups. P $\leq 0.05$ was considered to indicate a statistically significant difference and all values were two-sided. 
Table I. Clinical characteristics.

\begin{tabular}{lc}
\hline Characteristic & Data \\
\hline Gender, $\mathrm{n}(5)$ & \\
Male & $23(51.1)$ \\
Female & $22(48.9)$ \\
Age (years) & \\
Median age & 63 \\
Range & $39-81$ \\
ECOG, n (\%) & \\
0 & $12(26.7)$ \\
1 & $24(53.3)$ \\
2 & $9(20.0)$ \\
Stage of disease, $\mathrm{n}(\%)$ & $21(46.7)$ \\
IIIB & $24(53.3)$ \\
IV & \\
Smoking status, $\mathrm{n}(\%)$ & $31(68.9)$ \\
Former/current smoker & $14(31.1)$ \\
Never-smoker & \\
Number of cycles, $\mathrm{n}$ & 199 \\
Total & 4 \\
Median & $1-6$ \\
Range & \\
\hline
\end{tabular}

ECOG, Eastern Cooperative Oncology Group.

Table II. Distribution of TS, MTHFR and SLC19A1 genotypes.

\begin{tabular}{lcc}
\hline Genotype & db SNP id & $\mathrm{N}(\%)$ \\
\hline$T S$ & $\mathrm{rs} 45445694$ & \\
2R/2R & & $0(0)$ \\
2R/2C & & $7(15.6)$ \\
3C/3C & & $8(17.8)$ \\
2R/3G & & $12(26.7)$ \\
3G/3G & & $4(8.9)$ \\
3C/3G & & $14(31.1)$ \\
MTHFR C677T & & \\
CC & & $17(37.8)$ \\
CT & & $21(46.7)$ \\
TT & & $7(15.6)$ \\
SLC19A1 exon 6 (2522) C/T & rs1051298 & \\
CC & & $11(24.4)$ \\
CT & & $23(51.1)$ \\
TT & & $11(24.4)$ \\
\hline
\end{tabular}

SNP, single nucleotide polymorphism; TS, thymidylate synthase; MTHFR, methylenetetrahydrofolate reductase.

\section{Results}

Characteristics. Between August 2009 and December 2011, a total of 47 patients were enrolled in the trial conducted at the
Table III. Response rate and gene polymorphisms.

\begin{tabular}{lccc}
\hline Gene polymorphism & CR + PR & PD + SD & P-value \\
\hline$T S$ & & & 0.044 \\
2R/3G, 3C/3G, 3G/3G & 7 & 23 & \\
$2 \mathrm{R} / 2 \mathrm{R}, 2 \mathrm{R} / 3 \mathrm{C}, 3 \mathrm{C} / 3 \mathrm{C}$ & 8 & 7 & \\
MTHFR & & & 0.306 \\
$\mathrm{CC}$ & 8 & 9 & \\
$\mathrm{CT}$ & 5 & 16 & \\
$\mathrm{TT}$ & 2 & 5 & \\
SLC $19 A 1$ & & & 0.701 \\
$\mathrm{CC}$ & 3 & 8 & \\
$\mathrm{CT}$ & 9 & 14 & \\
$\mathrm{TT}$ & 3 & 8 & \\
\end{tabular}

$\mathrm{CR}$, complete response; $\mathrm{PR}$, partial response; $\mathrm{PD}$, progressive disease; TS, thymidylate synthase; MTHFR, methylenetetrahydrofolate reductase.

Lianyungang hospital, which is affiliated with Bengbu Medical College. Two patients refused additional treatment after the first cycle administration due to grade 4 neutropenia. There were no significant differences in the baseline characteristics of the 45 patients and all the patients had adenocarcinoma. The median age was 63 years (range, 39-81 years). The characteristics of all the patients are shown in Table I.

Genotypes. The gene information was obtained from the HapMap database. Table II shows the genotype distributions of TS, MTHFR and SLC19A1. The distributions of the genetic variants followed the Hardy-Weinberg equilibrium $(\mathrm{P}>0.05)$.

Association between gene polymorphisms and the treatment response to pemetrexed. There were 14 patients in the study who achieved a PR, eight with PD, 22 with SD and one who achieved a CR. The overall response rate (ORR; CR + PR) was $33.3 \%$ (15/45). All 45 patients had evaluable data for analysis. No significant associations were observed between the response rate and polymorphisms of $M T H F R$ and SLC19A1. Patients with $2 \mathrm{R} / 2 \mathrm{R}, 2 \mathrm{R} / 3 \mathrm{C}$ or $3 \mathrm{C} / 3 \mathrm{C}$ genotypes had a significantly higher $\mathrm{RR}$ than patients with $2 \mathrm{R} / 3 \mathrm{G}$, $3 \mathrm{C} / 3 \mathrm{G}$ or $3 \mathrm{G} / 3 \mathrm{G}$ genotypes $(53.3$ vs. $23.3 \%$, respectively; $\mathrm{P}=0.044$; Table III).

Survival analysis in patients with gene polymorphisms. According to the Kaplan-Meier survival analysis, patients with the $T S 2 \mathrm{R} / 2 \mathrm{R}, 2 \mathrm{R} / 3 \mathrm{C}$ or $3 \mathrm{C} / 3 \mathrm{C}$ genotypes had a significantly longer median PFS than patients with the $2 \mathrm{R} / 3 \mathrm{G}$, $3 \mathrm{C} / 3 \mathrm{G}$ or $3 \mathrm{G} / 3 \mathrm{G}$ genotypes (6.8 vs. 3.8 months, respectively; log-rank x $2=4.417 ; \mathrm{P}=0.036$; Fig. 1A). However, no significant difference in OS was observed between the two groups $(\mathrm{P}=0.638$; Fig. 2A). The Kaplan-Meier survival analysis showed that PFS and OS did not differ for the three genotypes of MTHFR (PFS: CC, 5.6 months; CT, 3.8 months; TT, 5.8 months; log-rank x2 $=0.016 ; \mathrm{P}=0.992$; OS: 10.3 vs. 10.6 vs. 8.1 months, respectively; $\mathrm{P}=0.739$; Fig. $1 \mathrm{~B}$ and $2 \mathrm{~B}$ ). 
Table IV. PFS and OS according to SNPs.

\begin{tabular}{|c|c|c|c|c|c|c|}
\hline \multirow[b]{2}{*}{ Gene genotype } & \multicolumn{3}{|c|}{ PFS (months) } & \multicolumn{3}{|c|}{ OS (months) } \\
\hline & Median & $95 \% \mathrm{CI}$ & P-value & Median & $95 \%$ CI & P-value \\
\hline$T S$ & & & 0.036 & & & 0.638 \\
\hline $2 \mathrm{R} / 2 \mathrm{R}, 2 \mathrm{R} / 3 \mathrm{C}, 3 \mathrm{C} / 3 \mathrm{C}$ & 6.8 & $4.3-9.3$ & & 10.3 & $6.5-12.7$ & \\
\hline $2 \mathrm{R} / 3 \mathrm{G}, 3 \mathrm{C} / 3 \mathrm{G}, 3 \mathrm{G} / 3 \mathrm{G}$ & 3.8 & $1.0-6.6$ & & 10.1 & $7.8-12.8$ & \\
\hline MTHFR & & & 0.992 & & & 0.739 \\
\hline $\mathrm{CC}$ & 5.6 & $3.7-7.5$ & & 10.3 & $7.6-13.0$ & \\
\hline $\mathrm{CT}$ & 3.8 & $1.6-6.0$ & & 10.6 & $4.6-16.6$ & \\
\hline TT & 5.8 & $0.0-12.5$ & & 8.1 & $4.5-11.7$ & \\
\hline SLC19A1 & & & 0.137 & & & 0.022 \\
\hline $\mathrm{CC}$ & 4.9 & $2.0-7.8$ & & 12.2 & $8.6-15.8$ & \\
\hline $\mathrm{CT}$ & 5.8 & $2.0-9.6$ & & 8.9 & $4.5-13.3$ & \\
\hline TT & 5.5 & $2.4-8.6$ & & 7.3 & $0.9-13.7$ & \\
\hline
\end{tabular}

PFS, progression-free survival; OS, overall survival; SNP, single nucleotide polymorphism; TS, thymidylate synthase; $M T H F R$, methylenetetrahydrofolate reductase.
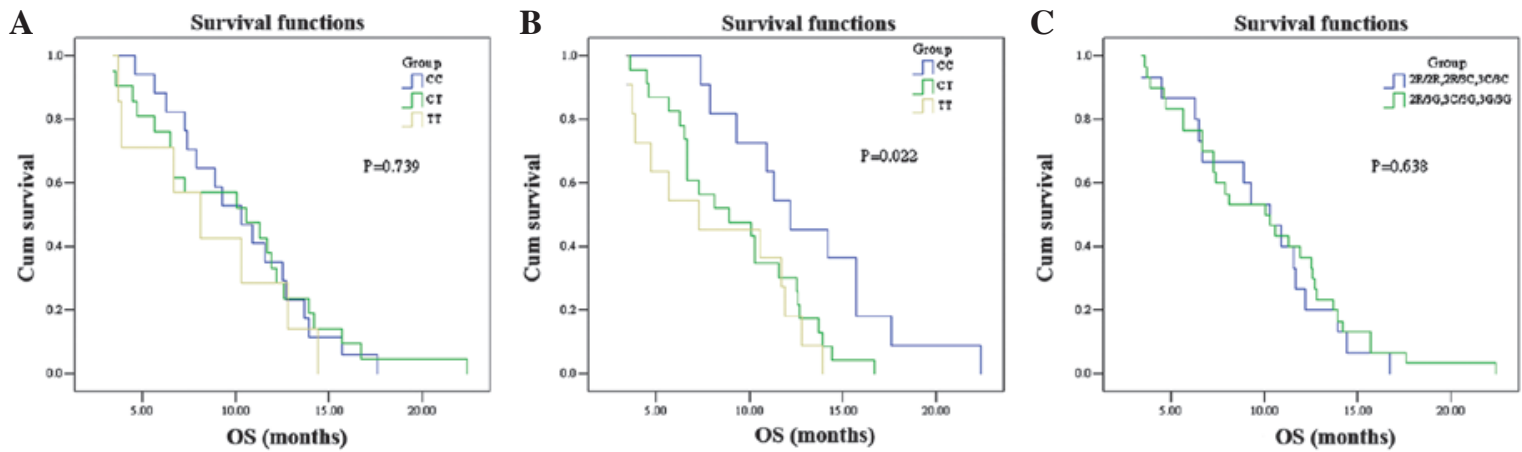

Figure 1. Kaplan-Meier curves estimating the association between the SNPs of the three genes and PFS of NSCLC patients treated with pemetrexed. (A) MTHFR, (B) SLC19A1 and (C) TS. SNPs, single nucleotide polymorphisms; PFS, progression-free survival; NSCLC, non-small cell lung cancer; TS, thymidylate synthase; $M T H F R$, methylenetetrahydrofolate reductase.
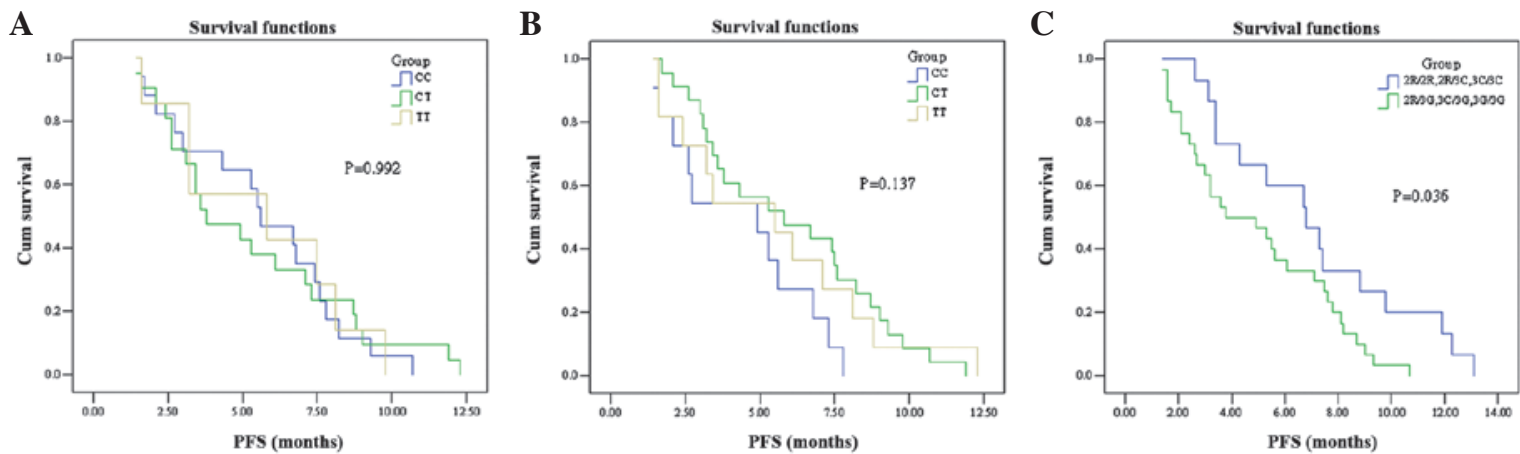

Figure 2. Kaplan-Meier curves estimating the association between the SNPs of the three genes and the OS of NSCLC patients treated with pemetrexed. (A) MTHFR, (B) SLC19A1 and (C) TS. SNPs, single nucleotide polymorphisms; OS, overall survival; NSCLC, non-small cell lung cancer; TS, thymidylate synthase; MTHFR, methylenetetrahydrofolate reductase.

No significant association was observed between the PFS of patients with the SLC19Al CC genotype and patients with the $\mathrm{CT}$ and TT genotypes $(\log$-rank $\mathrm{x} 2=3.976 ; \mathrm{P}=0.137$; Fig. 1C). However, patients with the SLC19Al CC genotype had a longer OS compared with the other two groups (12.2 vs. 8.9 and 7.3 months, respectively; $\mathrm{P}=0.022$; Fig. $2 \mathrm{C}$ ). The PFS and OS summaries based on SNP analysis are shown in Table IV. 


\section{Discussion}

The present study was conducted to investigate the association of polymorphisms in pemetrexed-related genes with the clinical outcome in advanced NSCLC. The results suggest that the polymorphisms in the TS 5'-untranslated region (UTR) may result in differences in the PFS of NSCLC patients treated with pemetrexed-based chemotherapy. The response rate was higher in patients with the $T S 2 \mathrm{R} / 2 \mathrm{R}, 2 \mathrm{R} / 3 \mathrm{C}$ or $3 \mathrm{C} / 3 \mathrm{C}$ genotypes. Patients with the SLC19A1 exon 6 (2522) CC genotype had improved OS when treated with pemetrexed compared with the patients without the genotype. However, a large-scale randomized prospective clinical trial is required to confirm these findings.

The TS gene is located on chromosome 18p11.32 and the enzyme encoded by it is essential for cell proliferation as it catalyzes the methylation of deoxyuridine-5'-monophosphate (dUMP) to form deoxythymidine-5'-monophophate (dTMP). It is known that $T S$ is a potential target for fluoropyrimidine and other drugs, including capecitabine, raltitrexed and pemetrexed. The promoter enhancer region of the $T S$ gene is prone to polymorphisms with double or triple repeats of 28-bp tandem repeats in the 5'-UTR. Mandola et al reported that the 3R alleles have a G>C SNP at the 12th position of the second repeat (20). Based on this SNP and the TS genotype, the $2 \mathrm{R} / 3 \mathrm{G}, 3 \mathrm{C} / 3 \mathrm{G}$ and $3 \mathrm{G} / 3 \mathrm{G}$ genotypes were considered to be high expression types and the $2 \mathrm{R} / 2 \mathrm{R}, 2 \mathrm{R} / 3 \mathrm{C}$ and $3 \mathrm{C} / 3 \mathrm{C}$ genotype were considered to be low expression types. However, no consensus was reached on the correlation between the $T S$ polymorphisms and efficacy of 5-FU. Several studies have noted that a C SNP was associated with longer PFS in colorectal cancer patients treated with 5-FU $(21,22)$. However, several other studies did not find any significant difference between $T S$ SNPs and the clinical outcome of patients treated with 5-FU (23-25).

Few studies have investigated the association between TS genotypes and the efficacy of pemetrexed. Smit et al showed that there was no correlation between the high and low TS expression genotypes and the clinical outcome of advanced NSCLC patients treated with pemetrexed $(16,17)$. In the present study, the PFS was significantly longer in patients with the $2 \mathrm{R} / 2 \mathrm{R}, 2 \mathrm{R} / 3 \mathrm{C}$ or $3 \mathrm{C} / 3 \mathrm{C}$ genotypes compared with patients with the $2 \mathrm{R} / 3 \mathrm{G}, 3 \mathrm{C} / 3 \mathrm{G}$ or $3 \mathrm{G} / 3 \mathrm{G}$ genotypes $(\mathrm{P}=0.036)$. However, no significant differences in OS were observed between the two groups $(\mathrm{P}=0.638)$. Further studies in larger populations are required to confirm these results, however, possible explanations include differences in the schedules of pemetrexed-based chemotherapy, types of lung cancer and ethnic populations.

MTHFR is a central regulatory enzyme involved in folate metabolism and the cellular concentrations of 5,10-methylenetetrahydrofolate are regulated by the activity of MTHFR (26). Moreover, optimal TS inhibition occurs when the cellular concentrations of 5,10-methylenetetrahydrofolate are elevated (27). The most common gene polymorphism linked with enzyme activity is MTHFR677 C/T (28). At present, the association between MTHFR SNPs and the efficacy of 5-FU is inconclusive and few studies have investigated the association of SNPs in this gene with the efficacy of pemetrexed. Jakobsen et al reported that the RR was significantly higher in patients with the MTHFR TT genotype compared with two other genotype groups in metastatic colorectal cancer patients treated with 5-FU (29). However, several large-scale clinical trials did not identify a clear association (30-32). Moreover, a large meta-analysis indicated that MTHFR $677 \mathrm{C} / \mathrm{T}$ is not a reliable predictor of the efficacy of FU-based therapy (33). Smit et al reported that patients with an MTHFR TT homozygous mutation had increased PFS compared with wild-type or heterozygous NSCLC patients treated with pemetrexed [7.9 months, $(95 \%$ CI, 3.9-16 months) vs. 2.9 months, (95\% CI, 2.8-3.4 months); $\mathrm{P}=0.03$ ] in (16). However, Argiris et al reported contrasting results (17). In the present study, no correlations were observed between the MTHFR genotypes and efficacy of pemetrexed in advanced adenocarcinoma lung cancer. It is possible that the present results were due to the small sample size of the study or due to only one SNP in MTHFR being investigated. This may have prevented the identification of possible pharmacogenetic associations, since drugs may exert their anticancer effects through multistep, multigenic cascades (30).

Pemetrexed is transported into cells by the RFC protein, which is encoded by the SLC19A1 gene. In previous studies, the SLC19A1 exon 6 (2522) CC genotype was observed to be associated with longer PFS and three-month progression-free status (progression-free at three months) in NSCLC patients treated with a combination of pemetrexed and bevacizumab chemotherapies (34). Adjei et al also demonstrated that a polymorphism in SLC19A1 may predict survival differences in pemetrexed-treated NSCLC patients (18). In the present study, patients with the SLC19A1 CC genotype had a longer median OS than patients with the other two genotypes $(12.2$ vs. 8.9 and 7.3 months, respectively; log-rank $\chi^{2}=2.957$; $\mathrm{P}=0.022$ ). The present results are similar to those of the two previously described trials.

In summary, polymorphisms in the 5'-UTR of the TS gene and exon $6(2522 \mathrm{C} / \mathrm{T})$ of the SLC19A1 gene appear to be potential prognostic factors for NSCLC patients treated with pemetrexed. Notably, germline polymorphisms have been reported to correlate with response and/or toxicity. The ultimate aim of this research is to aid the identification of the patients who are most likely to benefit from pemetrexed-based chemotherapy. Therefore, SNPs may be a useful tool for creating optimal individualized treatment regimens.

\section{Acknowledgements}

This study was funded by the Lianyungang Science and Technology Project (SH0805).

\section{References}

1. Jemal A, Siegel R, Ward E, Hao Y, Xu J, Murray T and Thun MJ: Cancer statistics, 2008. CA Cancer J Clin 58: 71-96, 2008.

2. Ries LAG, Melbert D, Krapcho M, Stinchcomb DG, Howlader N, Horner MJ, Mariotto A, Miller BA, Feuer EJ, Altekruse SF, Lewis DR, Clegg L, Eisner MP, Reichman M and Edwards BK, (eds). SEER Cancer Statistics Review, 1975-2005. National Cancer Institute, Bethesda, MD, 2008.

3. Ramalingam S and Belani C: Systemic chemotherapy for advanced non-small cell lung cancer: recent advances and future directions. Oncologist 13 (Suppl 1): 5-13, 2008.

4. Hanna N, Shepherd FA, Fossella FV, Pereira JR, De Marinis F, von Pawel J, Gatzemeier U, Tsao TC, Pless M, Muller T, Lim HL, Desch C, Szondy K, Gervais R, Shaharyar, Manegold C, Paul S, Paoletti P, Einhorn L and Bunn PA Jr: Randomized phase III trial of pemetrexed versus docetaxel in patients with non-small-cell lung cancer previously treated with chemotherapy. J Clin Oncol 22: 1589-1597, 2004 
5. Scagliotti GV, Parikh P, von Pawel J, Biesma B, Vansteenkiste J, Manegold C, Serwatowski P, Gatzemeier U, Digumarti R, Zukin M, Lee JS, Mellemgaard A, Park K, Patil S, Rolski J, Goksel T, de Marinis F, Simms L, Sugarman KP and Gandara D: Phase III study comparing cisplatin plus gemcitabine with cisplatin plus pemetrexed in chemotherapy-naive patients with advanced-stage non-small-cell lung cancer. J Clin Oncol 26: 3543-3551, 2008

6. Ciuleanu T, Brodowicz T, Zielinski C, Kim JH, Krzakowski M, Laack E, Wu YL, Bover I, Begbie S, Tzekova V, Cucevic B, Pereira JR, Yang SH, Madhavan J, Sugarman KP, Peterson P, John WJ, Krejcy K and Belani CP: Maintenance pemetrexed plus best supportive care versus placebo plus best supportive care for non-small-cell lung cancer: a randomised, double-blind, phase 3 study. Lancet 374: 1432-1440, 2009.

7. Chen JS, Chao Y, Bang YJ, Roca E, Chung HC, Palazzo F, Kim YH, Myrand SP, Mullaney BP, Shen LJ and Linn C: A phase I/II and pharmacogenomic study of pemetrexed and cisplatin in patients with unresectable, advanced gastric carcinoma. Anticancer Drugs 21: 777-784, 2010.

8. Chen CY, Chang YL, Shih JY, Lin JW, Chen KY, Yang CH, Yu CJ and Yang PC: Thymidylate synthase and dihydrofolate reductase expression in non-small cell lung carcinoma: The association with treatment efficacy of pemetrexed. Lung Cancer 74: 132-138, 2011.

9. Lorusso D, Ferrandina G, Pignata S, Ludovisi M, Viganò R, Scalone S, Scollo P, Breda E, Pietragalla A and Scambia G: Evaluation of pemetrexed (Alimta, LY231514) as second-line chemotherapy in persistent or recurrent carcinoma of the cervix: the CERVIX 1 study of the MITO (Multicentre Italian Trials in Ovarian Cancer and Gynecologic Malignancies) Group. Ann Oncol 21: 61-66, 2010

10. Mazzer M, Zanon E, Foltran L, De Pauli F, Cardellino G, Iaiza E, Ermacora P, Aprile G and Fasola G: Second-line pemetrexed-oxaliplatin combination for advanced pancreatic adenocarcinoma. J Clin Oncol 27 (Suppl): e15597, 2009.

11. Atkins JN, Jacobs SA, Wieand HS, Smith RE, John WJ, Colangelo LH, Vogel VG, Kuebler JP, Cescon TP, Miller BJ, Geyer CE Jr and Wolmark N: Pemetrexed/oxaliplatin for first-line treatment of patients with advanced colorectal cancer: A phase II trial of the National Surgical Adjuvant Breast and Bowel Project Foundation Research Program. Clin Colorectal Cancer 5: 181-187, 2005.

12. Pippen J, Elias AD, Neubauer M, Stokoe C, Vaughn LG, Wang Y, Orlando M, Shonukan O, Muscato J, O'Shaughnessy JA and Gralow J: A phase II trial of pemetrexed and gemcitabine in patients with metastatic breast cancer who have received prior taxane therapy. Clin Breast Cancer 10: 148-153, 2010.

13. Celio L, Sternberg CN, Labianca R, La Torre I, Amoroso V, Barone $\mathrm{C}$ et al: Pemetrexed in combination with oxaliplatin as a first-line therapy for advanced gastric cancer: a multi-institutional phase II study. Ann Oncol 20: 1062-1067, 2009.

14. Martinez-Balibrea E, Manzano JL, Martinez-Cardus A, Moran T, Cirauqui B, Catot S, Taron M and Abad A: Combined analysis of genetic polymorphisms in thymidylate synthase, uridine diphosphate glucoronosyltransferase and X-ray cross complementing factor 1 genes as a prognostic factor in advanced colorectal cancer patients treated with 5-fluorouracil plus oxaliplatin or irinotecan. Oncol Rep 17: 637-645, 2007.

15. Urano W, Taniguchi A, Yamanaka H, Tanaka E, Nakajima $H$, Matsuda $\mathrm{Y}$, Akama $\mathrm{H}$, Kitamura $\mathrm{Y}$ and Kamatani N: Polymorphisms in the methylenetetrahydrofolate reductase gene were associated with both the efficacy and the toxicity of methotrexate used for the treatment of rheumatoid arthritis, as evidenced by single locus and haplotype analyses. Pharmacogenetics 12 : $183-190,2002$.

16. Smit EF, Burgers SA, Biesma B, Smit HJ, Eppinga P, Dingemans AM, Joerger M, Schellens JH, Vincent A, van Zandwijk N and Groen HJ: Randomized phase II and pharmacogenetic study of pemetrexed compared with pemetrexed plus carboplatin in pretreated patients with advanced non-small cell lung cancer. J Clin Oncol 27: 2038-2045, 2009.

17. Argiris A, Karamouzis MV, Gooding WE, Branstetter BF, Zhong S, Raez LE, Savvides P and Romkes M: Phase II trial of pemetrexed and bevacizumab in patients with recurrent or metastatic head and neck cancer. J Clin Oncol 29: 1140-1145, 2011.

18. Adjei AA, Salavaggione OE, Mandrekar SJ, Dy GK, Ziegler KL, Endo C, Molina JR, Schild SE and Adjei AA: Correlation between polymorphisms of the reduced folate carrier gene (SLC19A1) and survival after pemetrexed-based therapy in non-small cell lung cancer. J Thorac Oncol 5: 1346-1353, 2010.
19. Therasse P, Arbuck SG, Eisenhauer EA, Wanders J, Kaplan RS, Rubinstein L, Verweij J, Van Glabbeke M, van Oosterom AT, Christian M and Gwyther SG: New guidelines to evaluate the response to treatment in solid tumors: European Organization for Research and Treatment of Cancer, National Cancer Institute of the United States, National Cancer Institute of Canada. J Natl Cancer Inst 92: 205-216, 2000.

20. Mandola MV, Stoehlmacher J, Muller-Weeks S, Cesarone G, $\mathrm{Yu}$ MC, Lenz HJ and Ladner RD. A novel single nucleotide polymorphism within the $5^{\prime}$ tandem repeat polymorphism of the thymidylate synthase gene abolishes USF-1 binding and alters transcriptional activity. Cancer Res 63: 2898-2904, 2003.

21. Kawakami K and Watanabe G: Identification and functional analysis of single nucleotide polymorphism in the tandem repeat sequence of thymidylate synthase gene. Cancer Res 63: 6004-6007, 2003.

22. Fernández-Contreras ME, Sánchez-Prudencio S, Sánchez-Hernández JJ, García de Paredes ML, Gisbert JP, Roda-Navarro P and Gamallo C: Thymidylate synthase expression pattern, expression level and single nucleotide polymorphism are predictors for disease-free survival in patients of colorectal cancer treated with 5-fluorouracil. Int J Oncol 28: 1303-1310, 2006.

23. Fariña-Sarasqueta A, Gosens MJ, Moerland E, et al: TS gene polymorphisms are not good markers of response to 5-FU therapy in stage III colon cancer patients. Cell Oncol (Dordr) 34: 327-335, 2011.

24. Vignoli M, Nobili S, Napoli C, et al: Thymidylate synthase expression and genotype have no major impact on the clinical outcome of colorectal cancer patients treated with 5-fluorouracil. Pharmacol Res 64: 242-248, 2011.

25. Ruzzo A, Graziano F, Loupakis F, Rulli E, Canestrari E, Santini D et al: Pharmacogenetic profiling in patients with advanced colorectal cancer treated with first-line FOLFOX-4 chemotherapy. J Clin Oncol 25: 1247-1254, 2007.

26. Marcuello E, Altés A, Menoyo A, Rio ED and Baiget M: Methylenetetrahydrofolate reductase gene polymorphisms: genomic predictors of clinical response to fluoropyrimidine-based chemotherapy? Cancer Chemother Pharmacol 57: 835-840, 2006

27. Longley DB, Harkin DP and Johnston PG: 5-fluorouracil: mechanisms of action and clinical strategies. Nat Rev Cancer 3: 330-338, 2003.

28. Frosst P, Blom HJ, Milos R, Goyette P, Sheppard CA, Matthews RG, Boers GJH, den Heijer M, Kluijtmans LA, van den Heuvel LP, et al: A candidate genetic risk factor for vascular disease: a common mutation in methylenetetrahydrofolate reductase. Nat Genet 10: 111-113, 1995.

29. Jakobsen A, Nielsen JN, Gyldenkerne N and Lindeberg J: Thymidylate synthase and methylenetetrahydrofolate reductase gene polymorphism in normal tissue as predictors of fluorouracil sensitivity. J Clin Oncol 23: 1365-1369, 2005

30. Ruzzo A, Graziano F, Kawakami K, Watanabe G, Santini D, Catalano V, Bisonni R, Canestrari E, Ficarelli R, Menichetti ET, Mari D, Testa E, Silva R, Vincenzi B, Giordani P, Cascinu S, Giustini L, Tonini G and Magnani M: Pharmacogenetic profiling and clinical outcome of patients with advanced gastric cancer treated with palliative chemotherapy. J Clin Oncol 24: 1883-1891, 2006.

31. Boige V, Mendiboure J, Pignon JP, Loriot MA, Castaing M, Barrois M, Malka D, Trégouët DA, Bouché O, Le Corre D, Miran I, Mulot C, Ducreux M, Beaune P and Laurent-Puig P: Pharmacogenetic assessment of toxicity and outcome in patients with metastatic colorectal cancer treated with LV5FU2, FOLFOX, and FOLFIRI: FFCD 2000-05. J Clin Oncol 28: 2556-2564, 2010.

32. Goekkurt E, Al-Batran SE, Hartmann JT, Mogck U, Schuch G, Kramer M,JaegerE, Bokemeyer C, Ehninger G and Stoehlmacher J: Pharmacogenetic analyses of a phase III trial in metastatic gastroesophageal adenocarcinoma with fluorouracil and leucovorin plus either oxaliplatin or cisplatin: a study of the arbeitsgemeinschaft internistische onkologie. J Clin Oncol 27: 2863-2873, 2009.

33. Zintzaras E, Ziogas DC, Kitsios GD, Papathanasiou AA, Lau $\mathrm{J}$ and Raman G: MTHFR gene polymorphisms and response to chemotherapy in colorectal cancer: a meta analysis. Pharmacogenomics 10: 1285-1294, 2009.

34. Adjei AA, Mandrekar SJ, Dy GK, Molina JR, Adjei AA, Gandara DR, Ziegler KL, Stella PJ, Rowland KM Jr, Schild SE and Zinner RG: A phase II trial of pemetrexed plus bevacizumab for second-line therapy of patients with advanced non-small cell lung cancer (NSCLC): an NCCTG and SWOG Study N0426. J Clin Oncol 28: 614-619, 2010. 